\section{A Comparison of Methods for RNA Extraction from Lymphocytes for RT-PCR}

\author{
W. Liedtke, ${ }^{1,2}$ L. Battistini, ${ }^{1,3}$ \\ C.F. Brosnan, ${ }^{1}$ \\ and C.S. Raine ${ }^{1}$
}

\begin{abstract}
${ }^{1}$ Albert Einstein College of Medicine, Department of Pathology, Division of Neuropathology, Bronx, New York 10461; ${ }^{2}$ University of Essen, Department of Neurology, 45122 Essen, Germany; ${ }^{3}$ University "La Sapienza", Department of Neurology, Rome, Italy
\end{abstract}

Various methods have been described to extract RNA from nonadherent mammalian cells or are provided in protocols accompanying various commercially available reagents. ${ }^{(1-10)}$ Reverse transcriptase-PCR (RT-PCR) allows the amplification, even the quantitation, of previously undetectable amounts of mRNA. ${ }^{(11,12)}$ In this burgeoning field, some major points of interest have not yet been investigated: (1) comparison of the cited methods (given the importance of RT-PCR, limiting dilutional assays of cDNA transcripts is a better end point than other RNA parameters like spectrophotometry, Northern blotting, etc.); (2) whether total RNA or poly(A) RNA extraction is more favorable for subsequent RT-PCR; and (3) a detailed comparison of cDNA synthesis with oligo(dT), random hexamer, or RT-PCR downstream primers.

We have addressed these questions by extracting RNA from human lymphocytes. The extracted RNA [either poly(A) or total] was reverse-transcribed, and the cDNA was subjected to PCR-amplifying $\beta$-actin, CD3, and $\gamma / \delta$ TCR rearrangement V反2J $\delta 1 .^{(13-15)}$

\section{MATERIALS AND METHODS Lymphocytes}

Peripheral blood mononuclear cells (PBMC) from two healthy males (31 and 32 years old) were isolated by the Ficoll Hypaque method. ${ }^{(16)}$ Cells were counted, and the cell suspension was either processed immediately or frozen in liquid nitrogen. We harvested $1.6 \times 10^{6}$ and $3 \times 10^{6} \mathrm{PBMC} / \mathrm{ml}$. The cells were cryoconserved in RPMI 1640 containing $10 \%$ fetal calf serum and $30 \%$ dimethylsulfoxide (DMSO) (all reagents from Sigma, St. Louis, MO). Cells were either pelleted by centrifuging for $5 \mathrm{~min}$ at $12,000 \mathrm{~g}$ or exposed to the lysis agent without centrifugation (volume 1:1). To estimate the effect of cell washing, one aliquot was washed three times with Hanks' balanced saline solution (HBSS) and one was left unwashed.

\section{RNA Extraction}

Nine different methods to extract total RNA and five to extract poly(A) RNA were applied to aliquots of the samples of PBMC (Table 1, Refs. 1-10). The following commercially available kits were

TABLE 1 Comparison of RNA Extraction Methods

\begin{tabular}{|c|c|c|c|c|c|c|c|}
\hline Method & According to & Ref. & RNA & $\beta$-actin ${ }^{a}$ & $\mathrm{CD}^{\mathrm{a}}$ & $\mathrm{V} \delta 2 \mathrm{~J} \delta 1^{\mathrm{a}}$ & $\begin{array}{l}\text { Labor } \\
\text { intensity }\end{array}$ \\
\hline 1 & Chomczynski & 1 & total & N.D. & $10^{-3}$ & N.D. & 2 \\
\hline 2 & Siebert and Chenchik & 2 & total & N.D. & $10^{-3}$ & N.D. & 4 \\
\hline 3 & Vauti + Siess & 6 & total & N.D. & $10^{-2}$ & N.D. & 2 \\
\hline 4 & Kamdar + Evans & 5 & total & N.D. & $10^{-2}$ & N.D. & 3 \\
\hline 5 & Zolfaghari & 8 & total & N.D. & $10^{-2}$ & N.D. & 3 \\
\hline 6 & Tavangar & 3 & total & N.D. & $10^{-2}$ & N.D. & 1 \\
\hline 7 & Iowa Biotech Corp. & 10 & total & $10^{-6}$ & $10^{-5}$ & $10^{-2}$ & 6 \\
\hline 8 & MRC, Inc. & 9 & total & $10^{-6}$ & $10^{-4.75}$ & $10^{-2}$ & 5 \\
\hline 9 & Biotecx, Inc. & - & total & $10^{-6}$ & $10^{-4.75}$ & $10^{-2}$ & 5 \\
\hline 10 & Hartmann; Celano & 4,7 & poly (A) & N.D. & $10^{-3.5}$ & N.D. & 5 \\
\hline 11 & Amresco, Inc. & - & poly(A) & N.D. & $10^{-4}$ & N.D. & 4 \\
\hline 12 & Invitrogen Corp. & - & poly (A) & $10^{-6}$ & $10^{-5}$ & $10^{-2}$ & 4 \\
\hline 13 & Dynal, Inc. & - & poly (A) & N.D. & $10^{-4}$ & N.D. & 5 \\
\hline 14 & Quiagen, Inc. & - & poly (A) & N.D. & $10^{-4}$ & N.D. & 6 \\
\hline
\end{tabular}

Fourteen different methods of RNA extraction [either total or poly $(A)$ ] were applied with limiting dilutional assays of three different transcripts ( $\beta$-actin, CD3, V82] $\delta 1$ ).

${ }^{a}$ The maximum dilution of cDNA with positive amplification (as measured by ethidium bromidestained agarose gels of PCR products) in $50 \%$ of replicate assays is given. The figures were obtained from $10^{6}$ lymphocytes. RNA was dissolved in $50 \mu \mathrm{l}$ of DEPC water. Ten microliters was reverse-transcribed with oligo(dT) in a total volume of $20 \mu \mathrm{l}$. One microliter of the latter was subjected to PCR or subsequently diluted. At least four replicate assays per dilutional step were run. (N.D.) Not determined.

'Subjective rating: (1) Most laborious; (6) most rapid and time saving. Criteria were total amount of time employed, number of centrifugation and washing steps, and convenience in terms of heating/cooling reagents and reactions. 
TABLE 2 Different PCR Assays Employed

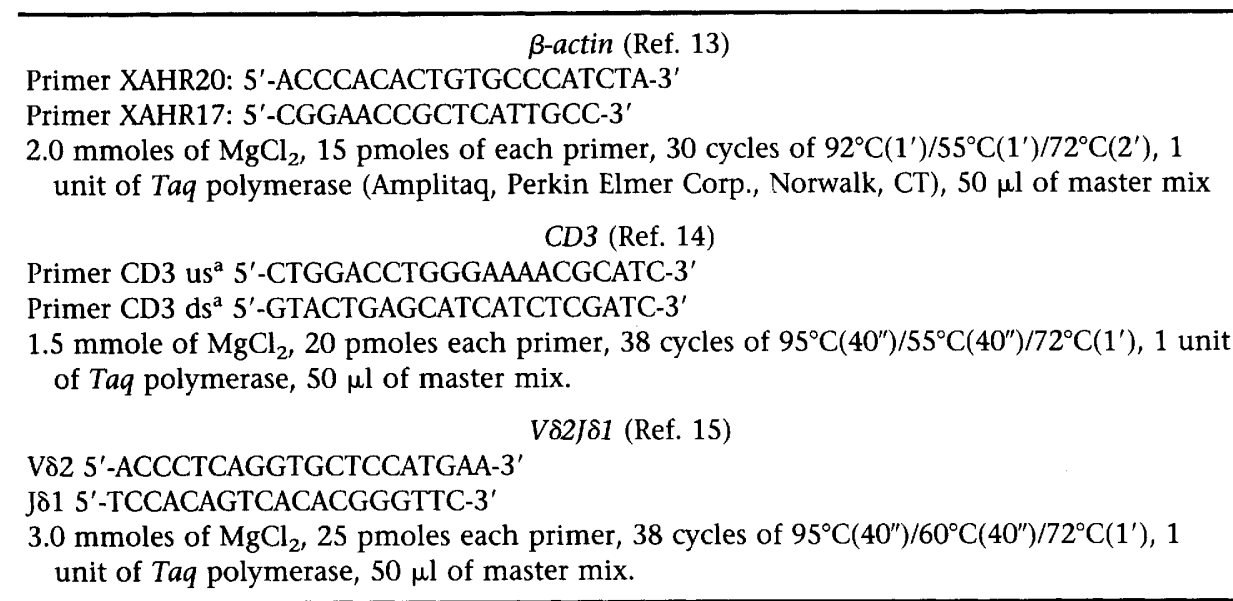

a(US) Upstream; (ds) downstream.

applied: Catrimox 14 (Iowa Biotechnology Corp., Oakdale), Dynabeads mRNA purification kit (Dynal Inc., Lake Success, NY), Microfast Track mRNA isola- tion kit (Invitrogen Corp., San Diego, CA), Oligotex direct mRNA kit (Quiagen Inc., Chatsworth, CA), rapid mRNA purification kit (Amresco Inc., Solon, $\mathrm{OH}$ ),
Tri Reagent [Molecular Research Center (MRC) Inc., Cincinatti, OH], and Ultraspec RNA isolation system (Biotecx Laboratories Inc., Houston, TX). Total RNA or poly(A) RNA was dissolved in 50 $\mu l$ of DEPC-treated water (the DEPC water was heat inactivated after $12 \mathrm{hr}$ of incubation).

\section{CDNA}

Ten of the 50- $\mu$ l samples were reversetranscribed in a $20-\mu$ l reverse transcriptase (RT) master mix using Superscript II RNase $\mathrm{H}^{-}$reverse transcriptase kit reagents and protocol (GIBCO BRL, Gaithersburg, MD). Random hexamer primers (150 pmoles) (Perkin Elmer Corp., Norwalk, CT), oligo(dT18) primer (150 pmoles) (New England Biolabs, Beverly, MA), or the downstream primer of the subsequent PCR (75 pmoles) (syn-
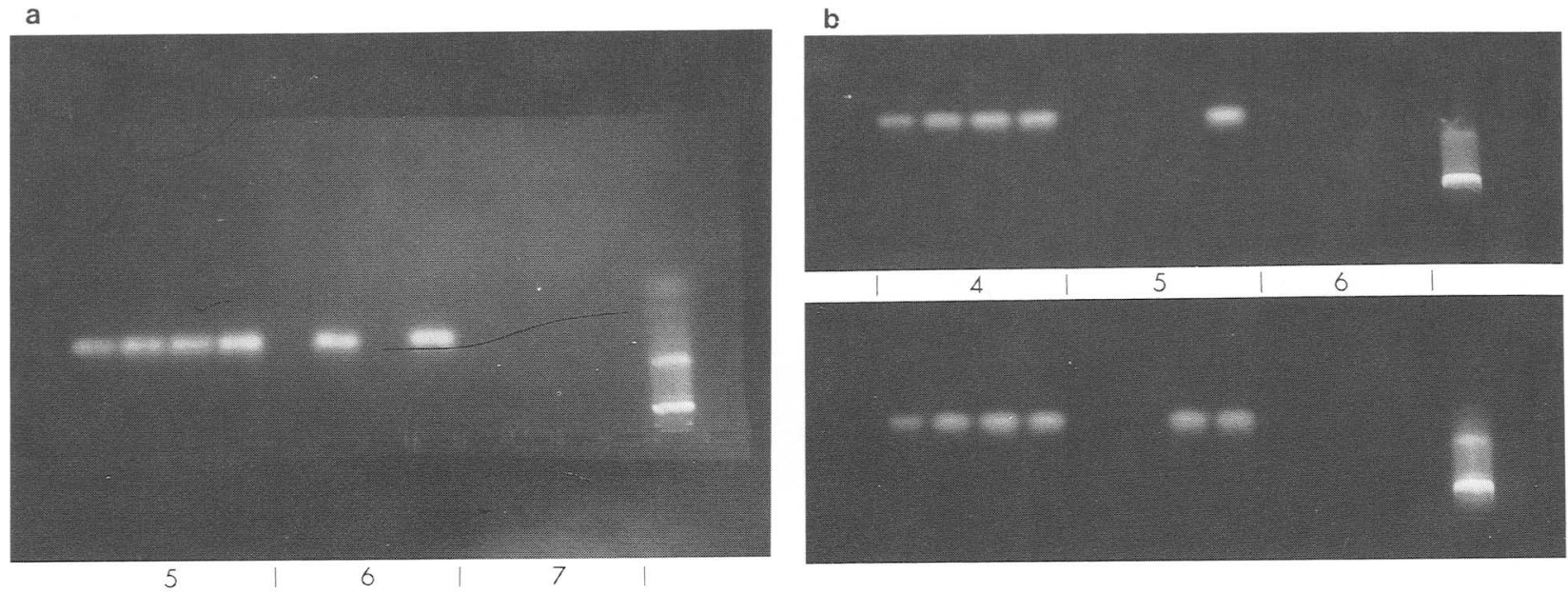

C

d
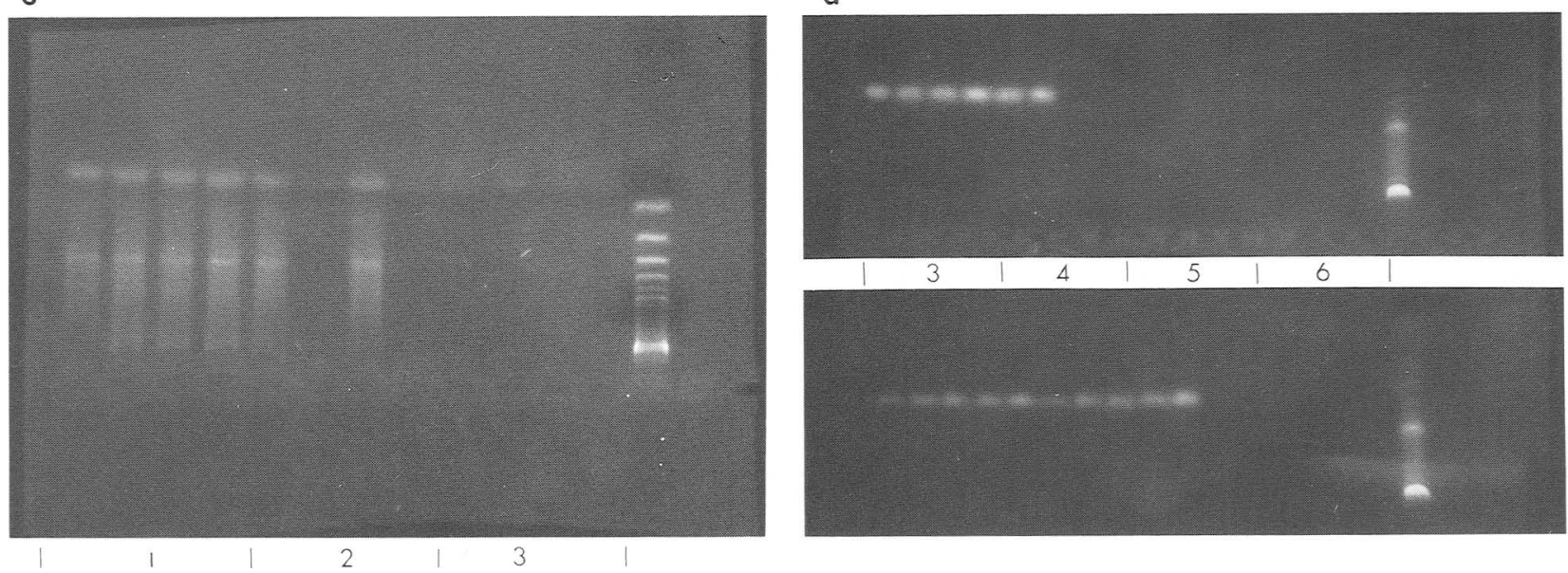

FIGURE 1 Ethidium bromide-stained $2 \%$ agarose gels of the PCR products. Quadruplicate assays per dilutional step were run. Dilution $10^{-x}$

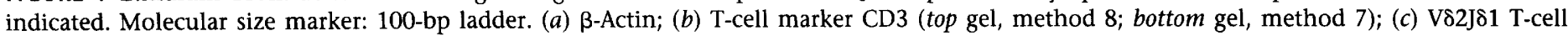
receptor rearrangement; $(d)$ reverse transcription with random hexamer primer (top gel) as compared with oligo(dT) (bottom gel), CD3 amplicon. 
thesized by Gene Link Inc., Thornwood, $\mathrm{NY}$ ) were used to initiate cDNA synthesis.

\section{PCR}

Three different PCR assays were run; details of the assays are shown in Table 2 . For each PCR, the master mix was prepared with either potassium chloride (500 $\mathrm{mm}$ in $10 \times$ buffer) or with potassium glutamate $(1000 \mathrm{~mm}$ in $10 \times$ buffer). ${ }^{(17)}$ Ethidium bromide-stained agarose gels showing PCR products are depicted in Figure 1.

\section{RESULTS AND DISCUSSION}

From this study, it became apparent that total RNA extraction with time-saving commercially available reagents and subsequent reverse transcription with either oligo(dT) or the RT-PCR downstream primer were the methods of choice for RT-PCR. In this setting the isolation of poly(A) RNA offered no particular advantage when compared with total RNA extraction.

Dilutional end points of $\beta$-actin, CD3, and $V \delta 2 J \delta 1$ transcripts and subjective ratings of labor intensity are given in Table 1 (for examples, see Figure 1). Hence, methods 7-9 and 12 are the methods of choice. Method 12 was more laborious and expensive. We consider the small differences in dilutional end points between these methods as nonsignificant. Labor intensity rendered method 7 the most favored when processing larger sample numbers. In addition, no phenol waste was produced and samples could be processed conveniently at room temperature. Additional points of importance include the observation that after reverse transcription with oligo(dT) or RT-PCR downstream primer, the dilutional end point of the subsequent PCR was 10-fold lower than with random hexamer primer (Fig. 1d) and that washed pelleted cells offered no advantage over unwashed cells. In addition, pelleting of the cells led to 10-100 lower dilutions than did direct exposure to the lysis agent. We also found that the same dilutions could be reached with cryoconserved or immediately processed cells and that DNA contamination could not be detected in total RNA processed according to methods $1-14$. Moreover, a temperature of $43^{\circ} \mathrm{C}$ for reverse transcription slightly increased the yield of cDNA in comparison with $37^{\circ} \mathrm{C}$. Finally, a PCR master mix containing potassium glutamate instead of potassium chloride offered no particular advantage.

Thus, although all methods had their merits, the method of choice for the work described is total RNA extraction with commercially available reagents.

\section{ACKNOWLEDGMENTS}

W.L. is the recipient of a scholarship from the Alexander von Humboldt Foundation, Feodor Lynen Program for German Fellows abroad, Bonn, Germany. This work was supported in part by grants NS 08952 and NS 11920 from the U.S. Public Health Service. L.B. is the recipient of a fellowship of the National Multiple Sclerosis Society. We thank W. Edelmann (Bronx, NY) and P. Salgame (Philadelphia, PA) for valuable suggestions on the manuscript.

\section{REFERENCES}

1. Chomczynski, P. and N. Sacchi. 1987. Single step method of RNA isolation by acid guanidinium thiocyanate-phenol-chloroform extraction. Anal. Biochem. 162: 156159 .

2. Siebert, P.D. and A. Chenchik. 1993. Modified acid guanidinium thiocyanate-phenol-chloroform RNA extraction method which greatly reduces DNA contamination. Nucleic Acids Res. 21: 2019-2020.

3. Tavangar, K., A.R. Hoffman, and F.B. Kraemer. 1990. A micromethod for the isolation of total RNA from adipose tissue. Anal. Biochem. 186: 60-63.

4. Hartmann, K.K.P., V. Papa, E.J. Brown, U. Doerries, S.M. Rosenthal, and I.D. Goldfine. 1990. A rapid and simple one step method for isolation of poly $(\mathrm{A})^{+}$RNA from cells in monolayer. Endocrinology 127: 2038-2040.

5. Kamdar, S.J. and R. Evans. 1992. Modifications of the guanidine hydrochloride procedure for the extraction of RNA: Isolation from a variety of tissues and adherent/nonadherent cell types. BioTechniques 12: $632-638$.

6. Vauti, F. and W. Siess. 1993. Simple method of RNA isolation from human leucocytic cell lines. Nucleic Acids Res. 21: 4852-4853.

7. Celano, P., P.M. Vertino, and R.A. Cesaro. 1993. Isolation of polyadenylated RNA from cultured cells and intact tissues. BioTechniques 15: 27-28.

8. Zolfaghari, R., X. Chen, and E.A. Fisher. 1993. Simple method for extracting RNA from cultured cells and tissue with guanidine salts. Clin. Chem. 39: 1408-1411.

9. Chomczynski, P. 1993. A reagent for the single-step simultaneous isolation of RNA, DNA and proteins from cell and tissue samples. BioTechniques 15: 532-537.

10. Dahle, C.E. and D.E. Macfarlane. 1993. Isolation of RNA from cells in culture using catrimox-14 $4^{\mathrm{TM}}$ cationic surfactant. BioTechniques 15: 1102-1104.

11. Kawasaki, E.S. and A.M. Wang. Detection of gene expression. 1989. In PCR: Principles and application for DNA amplification (ed. H.A. Erlich), p. 89. M. Stockton Press, New York.

12. Gause, W.C. and J. Adamovicz. 1994. The use of the PCR to quantitate gene expression. PCR Methods Applic. 3: S123-S135.

13. Du Breuil, R.M., J.M. Patel, and B.V. Mendelow. 1993. Quantitation of $\beta$-actin specific mRNA transcripts using xeno competitive PCR. PCR Methods Applic. 3: 5759.

14. Yamamura, M., K. Uyemura, R.J. Deans, K. Weinberg, R.H. Rea, B.R. Bloom, and R.L. Modlin. 1991. Defining protective responses to pathogens: Cytokine profiles in leprosy lesions. Science 254: 277-279.

15. Ohmen, J.D., P.F. Barnes, K. Uyemura, S. Lu, C.L. Grisso, and R.L. Modlin. 1991. The T cell receptors of human $\gamma \delta \mathrm{T}$ cells reactive to Mycobacterium tuberculosis are encoded by specific $\mathrm{V}$ genes, but diverse V-J junctions. J. Immunol. 147: 3353-3359.

16. Kuijpers T.W., A.T. Tool, C.E. van der Schoot, L.A. Ginsel, J.J. Onderwater, D. Roos, and A.J. Verhoeven. 1991. Membrane surface antigen expression on neutrophils: A reappraisal of the use of surface markers for neutrophil activators. Blood 78: 1105-1111.

17. Knorr, A., R.T. Turner, M.E. Bolander, and G. Sarkar. 1993. Stimulatory effect of potassium glutamate in PCR. PCR Methods Applic. 3: 73-74

Received August 23, 1994; accepted in revised form October 25, 1994. 


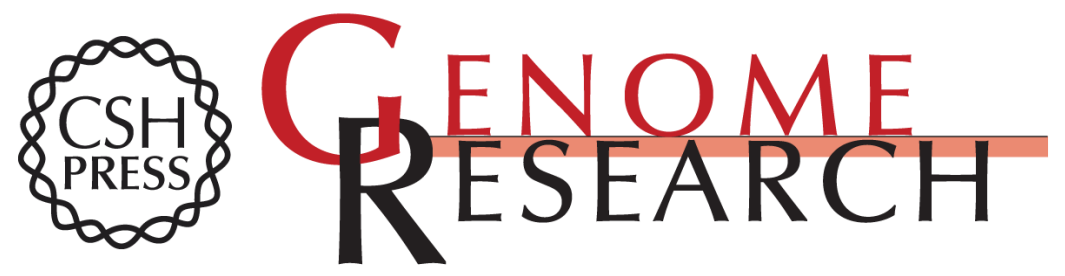

\section{A comparison of methods for RNA extraction from lymphocytes for RT-PCR.}

W Liedtke, L Battistini, C F Brosnan, et al.

Genome Res. 1994 4: 185-187

References This article cites 16 articles, 4 of which can be accessed free at: http://genome.cshlp.org/content/4/3/185.full.html\#ref-list-1

License

Email Alerting

Receive free email alerts when new articles cite this article - sign up in the box at the Service top right corner of the article or click here.

\section{Affordable, Accurate Sequencing.}

To subscribe to Genome Research go to: https://genome.cshlp.org/subscriptions 